\title{
Prevalence of abnormal Pap smear during pregnancy in a teaching hospital in South India
}

\author{
Varsha Mishra $^{1}$, Gowri Dorairajan ${ }^{2} *$, Siddaraju Neelaiah ${ }^{3}$, Palnivel Chinnakali $^{4}$
}

\author{
${ }^{1}$ JIPMER, Puducherry-605006, India \\ ${ }^{2}$ Department of Obstetrics \& Gynaecology, JIPMER, Puducherry-605006, India \\ ${ }^{3}$ Department of Pathology, JIPMER, Puducherry-605006, India \\ ${ }^{4}$ Department of Preventive and Social Medicine, JIPMER, Puducherry-605006, India
}

Received: 28 June 2015

Accepted: 14 August 2015

\author{
*Correspondence: \\ Dr. Gowri Dorairajan, \\ E-mail: gowridorai@hotmail.com
}

Copyright: (C) the author(s), publisher and licensee Medip Academy. This is an open-access article distributed under the terms of the Creative Commons Attribution Non-Commercial License, which permits unrestricted non-commercial use, distribution, and reproduction in any medium, provided the original work is properly cited.

\begin{abstract}
Background: The prevalence of cancer cervix is very high in our country. Women in our country typically present late when the disease is advanced. Screening during pregnancy gives an opportunity to pick up at pre-invasive/early stage as women come voluntarily seeking health care to hospitals. Abnormal cervical cytology is also associated with increased risk of adverse pregnancy outcome. This study was undertaken to determine the prevalence of abnormal Pap smear among pregnant women.

Methods: This cross sectional study was carried out in a teaching institution among pregnant women using conventional cytology (with Ayer's spatula) reported by Bethesda system after obtaining informed consent. The study was approved by institute ethics committee.

Results: Among the 316 women studied the mean (SD) age at marriage was 22 (3) years. The mean period of gestation was 30 weeks. Only one participant $(0.3 \%)$ reported high risk behaviour. The speculum examination was found to be normal in $99.7 \%$ women. There was one abnormal Pap smear report. Specific infection with Candida was reported in 14.6\%; in none of these the speculum examination showed a characteristic discharge of candidiasis. Further a significantly higher prevalence of Candida infection was found in rural compared to urban population (Chi square 3.7, $\mathrm{p}=0.046$ ).

Conclusions: The prevalence of abnormal Pap smear is particularly low at $0.3 \%$ in our study group. However the prevalence of asymptomatic Candida infection which was missed on speculum exam because of lack of the characteristic discharge was high at $14.6 \%$. Thus the authors recommend routine prenatal microbiological examination to detect candida infection.
\end{abstract}

Keywords: Abnormal Pap, Intraepithelial neoplasia, Screening, Pregnancy, Preterm labour

\section{INTRODUCTION}

The incidence of cervical cancer in our country is alarmingly high at 22-26.2 per lakh women and is the leading cancer in women in our country accounting for 147 deaths per lakh women in our country. ${ }^{1,2}$ Women who belong to low socio economic background, have minimal knowledge about the disease and are unaware of the screening facilities for cancer and even those aware are hesitant to seek screening due to social stigmas. Women in our country seek health care late after the disease starts producing symptoms. Antenatal period is a time when women come voluntarily to seek health care for pregnancy. This opportunity should be utilized to down stage cancer cervix by detection of pre invasive lesions with cytology. Abnormal Pap smear has also been reported to be associated with adverse pregnancy 
outcome like preterm labour etc. ${ }^{3,4}$ Therefore, this study is undertaken to determine the prevalence of abnormal Pap smears among pregnant women attending the antenatal clinics.

\section{METHODS}

This was a cross sectional study carried out in the antenatal clinics of the Department of Obstetrics of an Institute of National importance in Puducherry, south India. Taking the literature reported prevalence of abnormal smears as $8 \% 4$ and with a $3 \%$ precision, a sample size of 315 women was necessary. It was convenient sampling. The study was conducted from December 2014 to May 2015.

Pregnant women aged more than 21 years and who were married for more than three years attending antenatal clinic of teaching hospital were included in the study. Those detected with acute vaginal infections either on speculum examination or by symptoms and those with bleeding per vaginum were excluded. The study was approved by the institute ethics committee. Informed consent was obtained from women who fulfilled the inclusion criteria. Sterile speculum examination was carried out. Speculum findings were noted down. Cervical sample was collected from each pregnant woman for conventional Pap smear obtained using an Ayres spatula. Pap smear was reported using the Bethesda system terminology and stratified as normal, inflammation (specific or nonspecific), low grade or high grade squamous intra epithelial lesions or Human Papilloma Virus (HPV) related changes and invasive cervical cancer. Age, parity, socio economic status, age at marriage, high risk behaviour, history of smoking etc. were noted as per the proformas enclosed.

\section{RESULTS}

In total, 316 women completed the study. Baseline data of these women is shown in Table 1. The mean (SD) was 26 (3.6) years. Mean (SD) age at marriage was 22 (3) years. Mean period of gestation was 30 weeks. Only one participant $(0.3 \%)$ reported high risk behaviour. None of the women were smokers. Fourteen women $(4.4 \%)$ had taken oral contraceptive pills earlier. A past history of genital infection was forthcoming in $3.2 \%$ women.

Table 1: Baseline demographic characteristics of pregnant women attending antenatal clinic in a teaching hospital, Puducherry, 2015 (N=316).

\begin{tabular}{|llll|}
\hline \multirow{3}{*}{ Variable } & Categories & Frequency & $\%$ \\
& Para-0 & 80 & 25.3 \\
\cline { 2 - 4 } & Para-1 & 135 & 42.7 \\
\cline { 2 - 4 } & Para>1 & 101 & 32.0 \\
\hline \multirow{3}{*}{ Education } & Illiterate & 8 & 2.5 \\
\cline { 2 - 4 } & 5th-12th & 245 & 77.5 \\
\cline { 2 - 4 } & Graduate/diploma & 63 & 19.9 \\
\hline \multirow{2}{*}{$\begin{array}{l}\text { Period of } \\
\text { gestation }\end{array}$} & $<28$ weeks & 99 & 31.3 \\
\hline \multirow{2}{*}{ Occupation } & 28 weeks \& above & 217 & 68.7 \\
\cline { 2 - 4 } & Housewife & 296 & 93.7 \\
\hline \multirow{2}{*}{ Residence } & Employed & 20 & 6.3 \\
\cline { 2 - 4 } & Urban & 60 & 19.0 \\
\hline
\end{tabular}

Table 2: Association of demographic and obstetric characteristics with candida infection among pregnant women attending antenatal clinic in a teaching hospital, Puducherry, 2015 (N=316).

\begin{tabular}{|c|c|c|c|c|c|}
\hline \multirow{2}{*}{ Characteristic } & \multirow{2}{*}{ Total } & \multicolumn{2}{|c|}{ Candida infection } & \multirow{2}{*}{$\begin{array}{l}\text { Chi square } \\
\text { value }\end{array}$} & \multirow{2}{*}{ P value } \\
\hline & & Present [n (\%)] & Absent [n (\%)] & & \\
\hline \multicolumn{6}{|l|}{ Age groups (years) } \\
\hline $20-25$ & 170 & $28(16.5)$ & $142(83.5)$ & \multirow{3}{*}{1.1} & \multirow{3}{*}{0.578} \\
\hline $26-30$ & 115 & $14(12.2)$ & $101(87.8)$ & & \\
\hline$>30$ & 31 & $4(12.9)$ & $27(87.1)$ & & \\
\hline \multicolumn{6}{|l|}{ Place of residence } \\
\hline Urban & 60 & $4(6.7)$ & $56(93.3)$ & \multirow{2}{*}{3.7} & \multirow{2}{*}{$0.046^{*}$} \\
\hline Rural & 256 & $42(16.4)$ & $214(83.6)$ & & \\
\hline \multicolumn{6}{|l|}{ Parity } \\
\hline Para-0 & 80 & $7(8.8)$ & $73(91.3)$ & \multirow{3}{*}{2.9} & \multirow{3}{*}{0.232} \\
\hline Para-1 & 135 & $22(16.3)$ & $113(83.7)$ & & \\
\hline Para $>1$ & 101 & $17(16.8)$ & $84(83.2)$ & & \\
\hline \multicolumn{6}{|l|}{ Education } \\
\hline Illiterate & 8 & $1(12.5)$ & $7(87.5)$ & \multirow{3}{*}{2.8} & \multirow{3}{*}{0.238} \\
\hline Middle/high school & 245 & $40(16.3)$ & $205(83.5)$ & & \\
\hline Graduation or more & 63 & $5(7.9)$ & $58(92.1)$ & & \\
\hline \multicolumn{6}{|l|}{ Period of gestation } \\
\hline$<28$ weeks & 99 & $10(10.1)$ & $89(89.9)$ & \multirow{2}{*}{2.3} & \multirow{2}{*}{0.129} \\
\hline$>28$ weeks & 217 & $36(16.6)$ & $181(83.4)$ & & \\
\hline
\end{tabular}


The speculum examination was found to be normal in 99.7\% women. Pap smear was found to be satisfactory in 98.7\% women. There was one abnormal Pap report. Specific infection with Candida species was reported in $14.6 \%$ and Trichomonas vaginalis in one patient; in none of these, the speculum examination showed a characteristic discharge and it was noted as usual mucoid discharge of pregnancy.

On further analysis we found a significantly higher occurrence of Candida infection in rural compared to urban population (Chi square 3.7, $\mathrm{p}=0.046$ ). Candida was more frequently found in women with lower education $(90 \%)$ than in women with education beyond school $(10 \%)$. It was found to be higher in multiparous women and in women with more than 28 weeks period of gestation. However these three associations did not reach statistical significance (Table 2).

\section{DISCUSSION}

In our study the Pap smear was satisfactory in $98.7 \%$. Only one woman was found to have abnormal Pap (Atypical squamous cells of unknown significance). She was 36 years old, third gravida and was married at 25 years of age.

It is important to note that in our study $14.6 \%$ were found to have candidiasis. These cases were asymptomatic and the speculum examination found only mucoid discharge not suspicious of typical Candida associated discharge. Prevalence of asymptomatic Candida infection to the tune of $20-30 \%$ has been reported by various authors. ${ }^{5,6}$ In a study by Farr and Kiss, routine antenatal screening for Candida and Trichomonas vaginalis and treating them was found to be associated with significantly lower risk (nearly 2.5 times lower) of preterm birth. ${ }^{7}$ Similar observation was made in an open label placebo controlled randomized trial, ${ }^{6}$ where the authors found that treatment of asymptomatic Candida infection is associated with lower risk (OR 0.33) of preterm delivery.

In a study carried out on 344 women by Leli et al.; asymptomatic infections with Candida was found to be significantly higher in pregnant women (31.4\%) compared to non-pregnant woman $(19.9 \%) .^{8}$

In our study, we found that asymptomatic Candida infection was found to be significantly higher in the rural population. Lower education status, higher gestational age, higher parity was also found to be associated with higher (though not statistically significant) occurrence of asymptomatic Candida infection. Similar observation was made by Sreshta and colleagues in their study on 200 pregnant women in Kathmandu. ${ }^{9}$

Prevalence of abnormal Pap smear of $7-20 \%$ has been reported during pregnancy. ${ }^{4,10,11}$ In the study by Seda and colleagues, ${ }^{12}$ who found an incidence of $6.8 \%$ of abnormal Pap during pregnancy, $66.5 \%$ of those with abnormal Pap were married by 17 years and $78 \%$ had more than one sex partner.

The prevalence of abnormal Pap smear in our study group was found to be particularly low at $0.3 \%$. A low incidence has been reported in yet another study from India on 100 pregnant women. ${ }^{13}$ The authors found that 99\% Pap smears were satisfactory. Six of them had koilocytic changes but none of them showed squamous intraepithelial lesion.

In our study lack of high risk behaviour, smoking and higher age groups of marriage could be the possible reasons for lower prevalence of abnormal Pap smears.

\section{CONCLUSION}

The abnormal Pap is particularly low at $0.3 \%$ in our study group. However the prevalence of asymptomatic Candida infection was high at $14.6 \%$. These cases were not suspected even on speculum examination. So the authors recommend routine microbiological screening of pregnant women for Candida infection as they are likely to be missed even at routine speculum examination.

\section{ACKNOWLEDGEMENTS}

The study was carried out under the Golden Jubilee student research for undergraduate students initiated by the institute.

Funding: No funding sources Conflict of interest: None declared

Ethical approval: The study was approved by the institutional ethics committee

\section{REFERENCES}

1. National Centre for Disease Informatics Research. National Cancer Registry Programme, ICMR Three Year Report of Population Based Registries, 20092011. Bangalore, India: NCDIR-NCRP (ICMR); 2014.

2. Castellsagne X, de Sanjose S, Aguado T, Louie KS, Bruni L, Muñoz J, et al. HPV and cervical cancer in the world. 2007 report. WHO/ICO information centre on HPV and cervical cancer. Vaccine. 2007;25(Suppl 3):C1-C26.

3. He Y, Wu YM, Wang T, Song F, Wang Y, Zhu L. Perinatal outcomes of pregnant women with cervical intraepithelial neoplasia. Arch Gynecol Obstet. 2013;288:1237-42.

4. Hong JN, Berggren EK, Campbell SL, Smith JS, Rahangdale L. Abnormal cervical cancer screening in pregnancy and preterm delivery. Paediatr Perinat Epidemiol. 2014;28:297-301.

5. Aguin TJ, Sobel JD. Vulvovaginal candidiasis in pregnancy. Curr Infect Dis Rep. 2015;17:462.

6. Roberts CL, Algert CS, Rickard KL, Morris JM. Treatment of vaginal candidiasis for the prevention 
of preterm birth: a systematic review and metaanalysis. Syst Rev. 2015;4:31.

7. Farr A, Kiss H, Hagmann M, Marschalek J, Husslein $\mathrm{P}$, Petricevic L. Routine use of an antenatal infection screen-and-treat program to prevent preterm birth: long-term experience at a tertiary referral center. Birth. 2015;42:173-80.

8. Leli C, Mencacci A, Meucci M, Bietolini C, Vitali $\mathrm{M}$, Farinelli S, et al. Association of pregnancy and Candida vaginal colonization in women with or without symptoms of vulvovaginitis. Minerva Ginecol. 2013;65:303-9.

9. Shrestha S, Tuladhar NR, Basnyat S, Acharya GP, Shrestha P, Kumar P. Prevalence of vaginitis among pregnant women attending Paropakar Maternity and Women's Hospital, Thapathali, Kathmandu, Nepal. Nepal Med Coll J. 2011;13:293-6.

10. Khaengkhor $\mathrm{P}$, Mairaing $\mathrm{K}$, Suwannarurk $\mathrm{K}$, Thaweekul Y, Poomtavorn Y, Pattaraarchachai J, et al. Prevalence of abnormal cervical cytology by liquid based cytology in the antenatal care clinic, Thammasat University Hospital. J Med Assoc Thai. 2011;94:152-8.

11. McIntyre-Seltman K, Lesnock JL. Cervical cancer screening in pregnancy. Obstet Gynecol Clin North Am. 2008;35:645-58.

12. Seda J, Avellanet Y, Roca FJ, Hernández E, Umpierre SA, Romaguera J. Risk factors for abnormal cervical cytology in pregnant women attending the high-risk obstetrics clinic at the University Hospital in San Juan, Puerto Rico. P R Health Sci J. 2011;30:14-7.

13. Khanuja E, Ghosh UK, Garg P, Tomar G, Madan M, Bansal R. A study of cervical intraepithelial neoplasia in pregnancy. J Obstet Gynaecol India. 2014;64:193-6.

Cite this article as: Mishra V, Dorairajan G, Neelaiah S, Chinnakali P. Prevalence of abnormal Pap smear during pregnancy in a teaching hospital in South India. Int J Reprod Contracept Obstet Gynecol 2015;4:1296-9. 